\title{
EFEKTIVITAS KOMBINASI PUPUK ORGANIK PLUS DAN ANORGANIK BERBASIS LEISA TERHADAP PERTUMBUHAN DAN HASIL BAWANG MERAH
}

\section{THE EFFECTIVENESS OF LEISA-BASED ORGANIC PLUS AND INORGANIC FERTILIZER COMBINATION ON SHALLOT GROWTH AND YIELD}

\author{
Nurul Fadillah ${ }^{1}$, Gusti Ayu Kade Sutariati ${ }^{2 *}$, Tresjia Corina Rakian ${ }^{2}$ \\ ${ }^{1}$ Program Studi Agronomi, Pascasarjana, Universitas Halu Oleo \\ Jl. H.E.A Mokodompit, Kota Kendari 93231, Indonesia
}

\begin{abstract}
ABSTRAK
Penelitian ini bertujuan untuk mengkaji bagaimana pengaruh teknik LEISA terhadap pertumbuhan dan hasil tanaman bawang merah lokal di Kota Baubau, mengkaji bagaimana pengaruh teknik LEISA terhadap pertumbuhan dan hasil tanaman bawang merah lokal di Kota Baubau dan mengkaji perlakuan yang memberi pengaruh terbaik terhadap pertumbuhan dan hasil tanaman bawang merah lokal di Kota Baubau. Penelitian ini dilaksanakan di Laboratorium Lapangan Sekolah Menengah Kejuruan Negeri 5 (SMKN 5) Kecamatan Gonda Baru, Kota Baubau, Sulawesi Tenggara yang berlangsung pada bulan November 2020 sampai Februari 2021. Penelitian ini dilaksanakan menggunakan Rancangan Acak Kelompok Tunggal (RAK) dengan perlakuan Teknik LEISA yang terdiri atas 6 (enam) taraf yaitu $\mathrm{P}_{0}=$ Tanpa aplikasi, $\mathrm{P}_{1}=$ Pupuk Organik 5 ton ha $1, \mathrm{P} 2=$ Pupuk NPK Majemuk $250 \mathrm{~kg} \mathrm{ha}^{-1}, \mathrm{P}_{3}=$ Pupuk Organik 5 ton ha ${ }^{-1}+$ Pupuk NPK Majemuk $250 \mathrm{~kg}$ ha 1 , P4= Pupuk Organik 5 ton ha ${ }^{-1}+1 / 2$ Pupuk NPK Majemuk $250 \mathrm{~kg}$ ha $1, \mathrm{P} 5=$ Pupuk Organik 5 ton ha ${ }^{-1}+1 / 4$ Pupuk NPK Majemuk $250 \mathrm{~kg} \mathrm{ha}^{-1}$ Dengan demikian setiap perlakuan diulang 3 kali, sehingga terdapat 18 unit percobaan. Variabel yang diamati yaitu tinggi tanaman, jumlah daun, jumlah anakan, berat kering, jumlah umbi, berat umbi dan produksi per petak. Data hasil pengamatan dianalisis ragam dan data yang menunjukkan pengaruh nyata atau sangat nyata dilanjutkan dengan Uji Jarak Berganda Duncan (UJBD) pada taraf nyata $\alpha=0,05$. Hasil penelitian menunjukkan bahwa LEISA mampu meningkatkan pertumbuhan dan hasil tanaman bawang merah terutama pada variabel jumlah daun, jumlah anakan, bobot kering tanaman, jumlah umbi, berat umbi dan produksi per petak. Perlakuan sistem LEISA terbaik diperoleh pada perlakuan Pupuk Organik 5 ton $\mathrm{ha}^{-1}+$ Pupuk NPK Majemuk $250 \mathrm{~kg} \mathrm{ha}^{-1}$ (P3) dengan dibandingkan dengan kontrol.
\end{abstract}

Kata kunci: LEISA, pupuk organik, bawang merah

\begin{abstract}
The objective of how the effect of the LEISA technique on the growth and yield of local shallots in Baubau City, examine how the influence of the LEISA technique on the growth and yield of local shallots in Baubau City and examine the treatment that gives the best effect on the growth and yield of shallots. local red in Baubau City. This research was conducted at the Field Laboratory of State Vocational High School 5 (SMKN 5), Gonda Baru District, Baubau City, Southeast Sulawesi which took place from November 2020 to February 2021. This research was carried out using a Single-Cluster Randomized Design (RAK) with LEISA technique treatment that consists of 6 (six) levels, namely $P 0=$ No application, $P 1=$ Organic Fertilizer 5 tons ha-1, P2=Compound NPK Fertilizer $250 \mathrm{~kg}$ ha-1, P3=Organic Fertilizer 5 tons ha-1 + Compound NPK Fertilizer $250 \mathrm{~kg}$ ha-1 -1, P4= Organic Fertilizer 5 tons ha-1 + 1/2 Compound NPK Fertilizer $250 \mathrm{~kg}$ ha-1, P5= Organic Fertilizer 5 tons ha-1 + 1/4 Compound NPK Fertilizer $250 \mathrm{~kg}$ ha-1 .Thus every The treatment was repeated 3 times, so there were 18 experimental units. The variables observed were plant height, number of leaves, number of tillers, dry weight, number of tubers, tuber weight and production per plot. The observational data were analyzed for variance and the data that showed a real or very significant effect was continued with Duncan's Multiple Distance Test $(U J B D)$ at a significant level of $=0.05$. The results showed that LEISA was able to increase the growth and yield of shallots, especially on the variables of number of leaves, number of tillers, plant dry weight,
\end{abstract}

*) Penulis Korespondensi. 
number of tubers, tuber weight and production per plot. The best LEISA system treatment was obtained in the treatment of Organic Fertilizer 5 tons ha-1 + Compound NPK Fertilizer $250 \mathrm{~kg} \mathrm{ha-1} \mathrm{(P3)} \mathrm{compared}$ to the control.

Keywords: LEISA, organic fertilizer, shallot

\section{Pendahuluan}

Bawang merah (Allium ascalonicum L.) merupakan salah satu komoditas hortikultura di Indonesia yang mempunyai banyak manfaat. Bawang merah termasuk ke dalam kelompok rempah yang berfungsi sebagai bumbu penyedap makanan serta bahan obat tradisional (Tandi et al., 2015). Selain itu, bawang merah mengandung zat-zat gizi dan senyawa kimia aktif (senyawa sulfur) yang memiliki efek farmakologi, sehingga sangat bermanfaat bagi kesehatan. Kandungan zat gizi dalam umbi bawang merah dapat membantu sistem peredaran darah dan sistem pencernaan tubuh. Senyawa aktif seperti Alliin (SAC), Allisin, Adenosin, Dialil-disulfida sebagai antioksidan dan antivirus dalam umbi bawang merah yang berperan untuk menetralkan dan mengeluarkan zat-zat toksik berbahaya dari dalam tubuh (Aryanta, 2019). Kota Baubau adalah salah satu kota di Provinsi Sulawesi Tenggara. Kota ini memiliki topografi yang umumnya berupa permukaan yang bergunung, bergelombang dan berbukit-bukit. Di antara gunung dan bukit-bukit terbentang dataran yang merupakan daerah potensial untuk mengembangkan sektor pertanian. Oleh sebab itu, Kota Baubau memiliki tanaman unggulan yang banyak dibudidayakan oleh masyarakat setempat. Salah satu tanaman unggul Kota Baubau yaitu bawang merah (BPS, 2020).

Produktivitas budidaya tanaman bawang merah berkisar 3-12 t.ha ${ }^{-1}$ dengan rata-rata nasional 9,47 12 t.ha ${ }^{-1}$. Tahun 2019 Produksi tanaman bawang merah mencapai 1,52 juta ton (BPS, 2020). Sementara itu, produksi bawang merah di Kota Baubau mengalami penurunan dari tahun 2018, 2019 hingga 2020 yaitu sebesar 260 kwintal, 165 kwintal hingga 127 kwintal (BPS, 2021). Produktivitas bawang merah sangat bervariasi tergantung pada kondisi lahan, iklim, teknologi budidaya dan varietas yang digunakan. Penurunan produksi tanaman bawang merah di Kota Baubau disebabkan tingginya tingkat serangan penyakit dan kurangnya pengetahuan petani dalam budidaya tanaman bawang merah. Salah satunya yaitu penggunaan bibit yang tidak seragam dan bermutu rendah, kesuburan tanah yang rendah serta pengetahuan petani tentang teknologi budidaya bawang merah yang masih rendah. Pada umumnya, petani menggunakan disisihkan dari hasil panen sebelumnya yaitu benih tanpa perlakuan tertentu sehingga tidak dapat mempertahankan vigor dan viabilitasnya (Isniah, 2015).

Peningkatan produksi tanaman bawang merah selain menggunakan benih yang berkualitas, juga dapat dilakukan dengan cara pemupukan. Pemupukan bertujuan untuk menambah unsur hara di dalam tanah. Pemupukan digolongkan menjadi pupuk anorganik, pupuk organik dan pupuk hayati. Pupuk anorganik memiliki kelebihan untuk memperbaiki sifat kimia tanah. Penggunaan pupuk anorganik dapat menambahkan unsur hara yang tidak tersedia di dalam tanah sehingga dapat memberikan hasil tanaman yang optimal. Namun, pengunaan pupuk anorganik yang berlebihan akan berdampak terhadap penurunan kualitas tanah dan lingkungan. Sementara itu, pupuk organik dapat menyuburkan dan memperbaiki sifat biologi dan fisik tanah. Akan tetapi, ketersediaan unsur hara dari pupuk organik relatif kecil sehingga dalam meningkatkan produksi tanaman dibutuhkan dalam jumlah besar, hal ini berdampak pada naiknya biaya produksi tanaman (Pangaribuan et $a l ., 2017)$. Oleh karena itu, sistem pertanian Low External Input Sustainable Agriculture atau LEISA adalah sistem pertanian ramah lingkungan yang dapat mengkombinasikan penggunaan pupuk organik, pupuk hayati, dan pupuk anorganik dalam budidaya tanaman untuk meningkatkan pertumbuhan dan hasil tanaman.

Low External Input Sustainable Agriculture (LEISA) adalah sistem usahatani yang memanfaatkan sumber daya alam seperti pupuk organik serta agens hayati dalam bentuk pupuk hayati, namun penggunaan input luar dalam bentuk pupuk anorganik masih diperbolehkan dalam jumlah yang lebih rendah selama produk yang dihasilkan aman, sehat dan meminimalisir kerusakan lingkungan (Sutariati et al., 2014). Selain itu, sistem LEISA merupakan salah satu cara yang mungkin untuk menyelesaikan masalah nasional dan internasional seperti (1) ketahanan ketahanan pangan dan gizi, (2) pertanian berkelanjutan, dan (3) pertanian ramah lingkungan (Setiyo et al., 2017). Budidaya bawang merah menggunakan teknik Bio-Invigorasi benih dan LEISA mampu mengurangi ketergantungan petani terhadap 
pupuk anorganik, mampu meningkatkan pertumbuhan dan hasil tanaman serta mampu mempertahankan sistem dalam pertanian berkelanjutan yang ramah lingkungan. Oleh karena karena itu, kajian tentang penerapan teknik LEISA dalam meningkatkan pertumbuhan dan hasil tanaman bawang merah di kota Baubau menjadi penting untuk dilakukan.

\section{Metode Penelitian}

Penelitian ini dilaksanakan di Laboratorium Lapangan Sekolah Menengah Kejuruan Negeri 5 (SMKN 5) Kecamatan Gonda Baru, Kota Baubau, Sulawesi Tenggara. Penelitian ini berlangsung pada bulan November 2020 sampai Februari 2021. Bahan yang digunakan pada penelitian adalah benih bawang merah, kertas label, tissue, pematok kayu, tali rafia, ember dan gembor. Alat yang digunakan yaitu oven, timbangan analitik, gelas kimia, gelas ukur, kamera, parang, pacul, traktor, meteran dan alat tulis menulis.

Penelitian ini dilaksanakan menggunakan Rancangan Acak Kelompok Tunggal (RAK) dengan perlakuan Teknik LEISA yang terdiri atas 6 (enam) taraf yaitu $\mathrm{P}_{0}=$ Tanpa aplikasi, $\mathrm{P}_{1}=$ Pupuk Organik 5 ton ha 1, P2=Pupuk NPK Majemuk $250 \mathrm{~kg} \mathrm{ha}{ }^{-1}, \mathrm{P}_{3}=$ Pupuk Organik 5 ton $\mathrm{ha}^{-1}+$ Pupuk NPK Majemuk $250 \mathrm{~kg}^{-1}$ 1, P4= Pupuk Organik 5 ton $\mathrm{ha}^{-1}+1 / 2$ Pupuk NPK Majemuk $250 \mathrm{~kg}$ ha 1, P5 $=$ Pupuk Organik 5 ton ha ${ }^{-1}+1 / 4$ Pupuk NPK Majemuk $250 \mathrm{~kg} \mathrm{ha}^{-1}$ Dengan demikian setiap perlakuan diulang 3 kali, sehingga terdapat 18 unit percobaan.

Penelitian ini dilaksanakan dengan mempersiapkan lahan dilakukan dengan membersihkan lahan dari gulma dan pepohonan yang menghambat dalam pengolahan tanah. Pengolahan tanah dilakukan dengan menggunakan traktor sebanyak dua kali yaitu dengan bajak singkal. Lahan disingkal menghasilkan bongkahan tanah besar dan kemudian dilanjutkan dengan bajak rotari untuk menjadikan bongkahan besar menjadi bongkahan kecil (menggemburkan tanah). Setelah itu, membuat bedengan dengan ukuran bedengan $1 \mathrm{~m}$ x $1 \mathrm{~m}$ kemudian dilakukan pembuatan saluran drainase antara perlakuan $30 \mathrm{~cm}$. Jarak antara kelompok $80 \mathrm{~cm}$.

Persiapan umbi. Umbi yang digunakan untuk benih adalah umbi yang berukuran sedang ( $5 \mathrm{~g} / \mathrm{umbi}$ ), berasal dari panen pada umur yang cukup tua (khusus diproduksi untuk benih), tidak tercampur dengan varietas lain agar pertumbuhan dan umur panennya seragam. Benih yang digunakan untuk penelitian ini merupakan varietas lokal yang diperoleh dari petani bawang merah di daerah Lapandewa Kota Baubau.

Penanaman dilakukan dengan 1 benih bawang merah dalam setiap lubang dengan kedalaman tanam $\pm 3 \mathrm{~cm}(1 \mathrm{~cm}$ ujung benih bawang merah masih nampak di permukaan tanah).

Setelah tanaman berumur satu minggu dilakukan pemupukan pertama yaitu setengah dari dosis yang telah ditetapkan pada setiap petak perlakuan dengan sistem LEISA. Pupuk yang diberikan berupa pupuk organik (pupuk kandang sapi) dan pupuk anorganik (NPK majemuk) sesuai dengan dosis yang telah ditetapkan yaitu (P0) tanpa aplikasi, (P1) Pupuk Organik 5 ton ha ${ }^{1}$, (P2) Pupuk NPK Majemuk $250 \mathrm{~kg} \mathrm{ha}^{-1}$, (P3) Pupuk Organik 5 ton $\mathrm{ha}^{-1}+$ Pupuk NPK Majemuk $250 \mathrm{~kg} \mathrm{ha}^{-1},(\mathrm{P} 4)$ Pupuk Organik 5 ton ha ${ }^{-1}+1 / 2$ Pupuk NPK Majemuk $250 \mathrm{~kg} \mathrm{ha}^{-1}$, (P5) Pupuk Organik 5 ton $\mathrm{ha}^{-1}+1 / 4$ Pupuk NPK Majemuk $250 \mathrm{~kg} \mathrm{ha}^{-1}$. Pada umur tanaman 1 minggu dilakukan pemupukan setengah dosis dari dosis yang ditetapkan dan umur tanaman 4 minggu dilakukan pemupukan kedua dengan sistem yang sama yaitu setengah dosis lagi dari dosis yang ditetapkan pada setiap petak perlakuan.

Pemeliharaan tanaman meliputi penyiraman dan penyiangan. Penyiraman dilakukan dua kali yaitu pagi dan sore hari dengan tujuan untuk mempertahankan kadar air tanah kapasitas lapang. Penyiangan dilakukan dengan cara mencabut gulma atau tanaman pengganggu yang tumbuh pada petak percobaan sehingga tidak menimbulkan kompetisi dengan tanaman bawang merah dalam pemanfaatan unsur hara.

Variabel yang diamati yaitu tinggi tanaman (cm), jumlah daun (helai), jumlah anakan (anakan), berat kering tanaman (g), jumlah umbi (umbi), berat umbi $(\mathrm{g})$, dan produksi per petak. Data hasil pengamatan dianalisis dengan sidik ragam dan pabila menunjukkan pengaruh nyata $\left(\mathrm{F}_{\text {hitung }}>\mathrm{F}_{\text {tabel }}\right)$ maka dilanjutkan dengan Uji Jarak Berganda Duncan (Duncan's Multiple Range Test) pada taraf nyata $\alpha=0,05$.

\section{Hasil dan Pembahasan}

\section{Tinggi Tanaman}

Hasil penelitian menunjukkan bahwa perlakuan LEISA memberikan pengaruh yang signifikan terhadap pertumbuhan dan hasil tanaman bawang merah. Hasil UJBD taraf kepercayaan $95 \%$ pada pengaruh perlakuan 
LEISA terhadap tinggi tanaman disajikan pada Gambar 1.

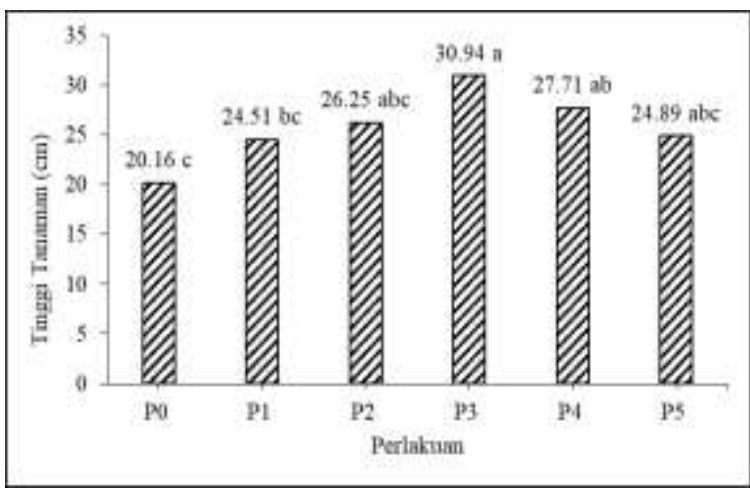

Gambar 1. Rata - rata tinggi tanaman bawang merah umur 56 HST yang diberikan perlakuan LEISA. Keterangan : Angka-angka yang diikuti oleh huruf yang tidak sama berbeda nyata pada UJBD taraf kepercayaan $95 \%$.

Hasil UJBD taraf kepercayaan 95\% pada Gambar 1. menunjukkan bahwa perlakuan tertinggi terhadap tinggi tanaman pada umur 56 HST diperoleh pada perlakuan pupuk organik 5 ton $\mathrm{ha}^{-1}+$ Pupuk NPK Majemuk $250 \mathrm{~kg} \mathrm{ha}^{-1}$ (P3), yang berbeda tidak nyata dengan perlakuan pupuk NPK Majemuk $250 \mathrm{~kg} \mathrm{ha}^{-1}$ (P2), dan perlakuan pupuk Organik 5 ton $\mathrm{ha}^{-1}+1 / 2$ Pupuk NPK Majemuk $250 \mathrm{~kg} \mathrm{ha}^{-1}(\mathrm{P} 4)$, dan perlakuan pupuk organik 5 ton $\mathrm{ha}^{-1}+1 / 4$ Pupuk NPK Majemuk $250 \mathrm{~kg} \mathrm{ha}^{-1}(\mathrm{P} 5)$, tetapi berbeda nyata dengan perlakuan tanpa aplikasi LEISA (P0). Hal ini menunjukkan bahwa perlakuan LEISA mampu meningkatkan tinggi tanaman bawang merah. Peningkatan tinggi tanaman bawang merah lokal diduga disebabkan adanya kombinasi dosis antara pupuk kandang dan pupuk NPK dengan komposisi dosis yang tepat dapat menyediakan unsur hara yang sesuai bagi kebutuhan tanaman sehingga meningkatkan pertumbuhan tanaman bawang merah. Rinasari et al. (2016) mengemukakan bahwa pemberian kombinasi pupuk organik dengan pupuk anorganik pada perbandingan tertentu dapat meningkatkan kualitas dan kuantitas tanaman. Hidayat et al. (2013) mengemukakan bahwa unsur nitrogen yang tersedia bagi tanaman dengan jumlah yang cukup dapat melancarkan metabolisme tanaman sehingga pertumbuhan batang semakin tinggi dan mempengaruhi jumlah daun.

\section{Jumlah Daun}

Hasil penelitian menunjukkan bahwa perlakuan LEISA memberikan pengaruh yang signifikan terhadap pertumbuhan dan hasil tanaman bawang merah. Hasil UJBD taraf kepercayaan $95 \%$ pada pengaruh perlakuan LEISA terhadap jumlah daun disajikan pada Gambar 2.

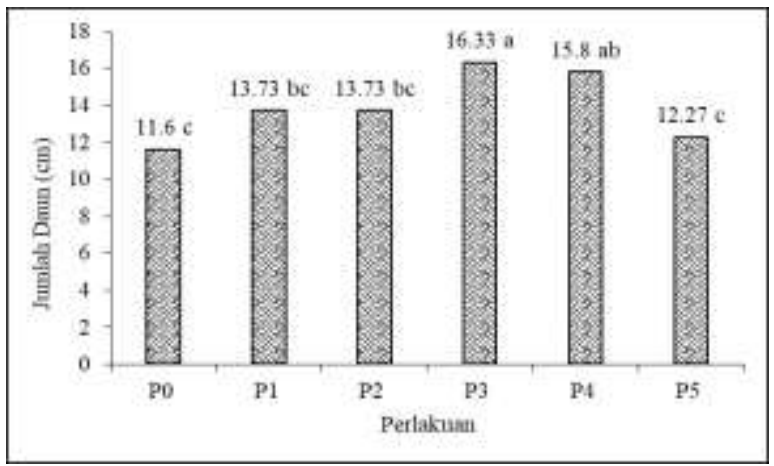

Gambar 2. Rata - rata jumlah daun tanaman bawang merah pada umur 56 HST yang diberikan perlakuan LEISA. Keterangan : Angkaangka yang diikuti oleh huruf yang tidak sama berbeda nyata pada UJBD taraf kepercayaan $95 \%$.

Hasil UJBD taraf kepercayaan $95 \%$ pada Gambar 2. menunjukkan bahwa teknik LEISA dengan perlakuan tertinggi terhadap jumlah daun diperoleh pada perlakuan P3 yang berbeda tidak nyata dengan perlakuan $\mathrm{P} 4$, tetapi berbeda nyata dengan perlakuan P0, P1, P2 dan P5. Hasil penelitian menunjukkan bahwa pemberian pupuk kandang dan pupuk NPK majemuk menghasilkan jumlah daun yang lebih banyak dibandingkan dengan perlakuan tanpa pemupukan. Pertumbuhan daun pada tanaman memerlukan zat hara terutama nitrogen, fosfor dan kalium. Nitrogen digunakan tanaman dalam pembentukan protein. Fosfor membantu dalam mempercepat pembentukan bunga, buah dan biji. Kalium berperan dalam pengangkutan karbohidrat, pembentukan dan pematangan buah. Pradita et al. (2018) melaporkan bahwa pembentukan daun dipengaruhi oleh unsur hara N, P, dan K.

\section{Jumlah Anakan}

Hasil penelitian menunjukkan bahwa perlakuan LEISA memberikan pengaruh yang signifikan terhadap pertumbuhan dan hasil tanaman bawang merah. Hasil UJBD taraf kepercayaan $95 \%$ pada pengaruh perlakuan LEISA terhadap jumlah anakan disajikan pada Gambar 3. 


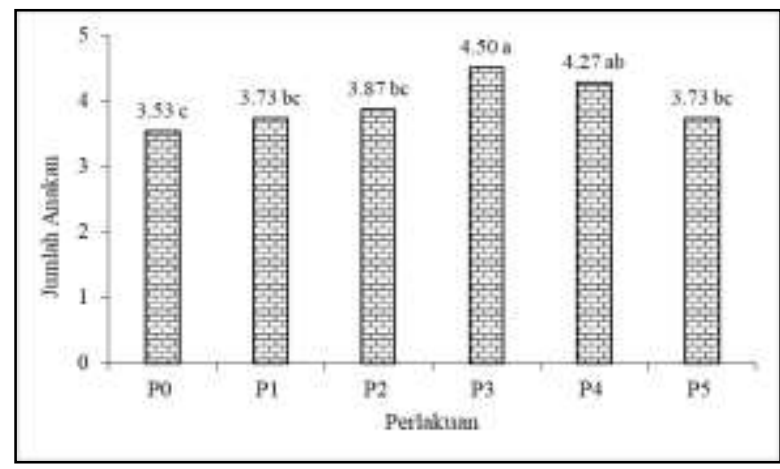

Gambar 3. Rata - rata jumlah anakan tanaman bawang merah pada umur 56 HST yang diberikan perlakuan LEISA. Keterangan : Angka-angka yang diikuti oleh huruf yang tidak sama berbeda nyata pada UJBD taraf kepercayaan $95 \%$.

Hasil UJBD taraf kepercayaan 95\% pada Gambar 3. menunjukkan bahwa teknik LEISA dengan perlakuan tertinggi terhadap jumlah anakan diperoleh pada perlakuan P3 yang berbeda tidak nyata dengan perlakuan $\mathrm{P} 4$, tetapi berbeda nyata dengan perlakuan P0, P1, P2, dan P5. Hasil penelitian menunjukkan bahwa kombinasi pupuk organik dan pupuk NPK majemuk berpengaruh sangat nyata terhadap jumlah anakan tanaman bawang merah, dimana nilai tertinggi terdapat pada $\mathrm{P} 4$ dan terendah pada kontrol, hal tersebut dikarenakan kombinasi pupuk organik dan pupuk NPK majemuk mampu meningkatkan unsur hara $\mathrm{N}, \mathrm{P}, \mathrm{K}$. Unsur hara nitrogen dapat merangsang pertumbuhan vegetatif tanaman, sedangkan penambahan unsur hara $\mathrm{P}$ akan menguatkan sistem perakaran tanaman sehingga dihasilkan anakan produktif yang banyak (Hidayati, 2010).

\section{Berat kering tanaman}

Hasil penelitian menunjukkan bahwa perlakuan LEISA memberikan pengaruh yang signifikan terhadap pertumbuhan dan hasil tanaman bawang merah. Hasil UJBD taraf kepercayaan $95 \%$ pada pengaruh perlakuan LEISA terhadap berat kering tanaman pada umur 56 HST disajikan pada Gambar 4.

Hasil UJBD taraf kepercayaan 95\% pada Gambar 4. menunjukkan bahwa teknik LEISA dengan perlakuan tertinggi terhadap berat kering tanaman diperoleh pada perlakuan P3 yang berbeda tidak nyata dengan perlakuan $\mathrm{P} 1$, tetapi berbeda nyata dengan perlakuan P4.

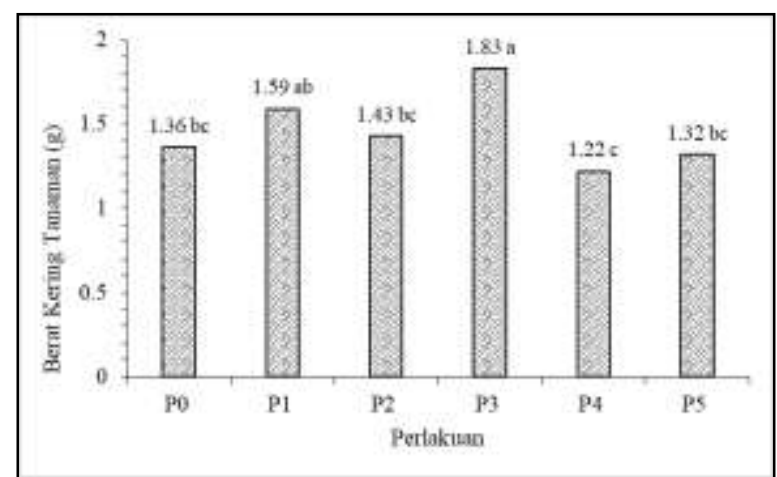

Gambar 4. Rata - rata berat kering tanaman bawang merah pada umur 56 HST yang diberikan perlakuan LEISA. Keterangan : Angkaangka yang diikuti oleh huruf yang tidak sama berbeda nyata pada UJBD taraf kepercayaan $95 \%$.

Hal ini menunjukkan bahwa pemberian perlakuan LEISA dengan kombinasi pupuk organik dan pupuk NPK majemuk mampu meningkatkan unsur hara yang dibutuhkan tanaman untuk melakukan pertumbuhan. Unsur nitrogen berperan dalam penyusunan semua senyawa protein, lemak, dan berbagai persenyawaan organik lainnya dan memberi pengaruh terhadap penggunaan karbohidrat di dalam tanaman. Penggunaan nitrogen berpengaruh langsung terhadap sintesis karbohidrat di dalam sel tanaman dan selanjutnya akan berpengaruh terhadap vigor tanaman dan pertumbuhan vegetatif yang meningkat (Damanik, 2011), hal ini menyebabkan tanaman tumbuh dengan baik dan mampu meningkatkan berat kering tanaman.

\section{Jumlah dan berat umbi}

Hasil penelitian menunjukkan bahwa perlakuan LEISA memberikan pengaruh yang signifikan terhadap pertumbuhan dan hasil tanaman bawang merah. Hasil UJBD taraf kepercayaan $95 \%$ pada pengaruh perlakuan LEISA terhadap jumlah dan berat umbi disajikan pada Gambar 5.

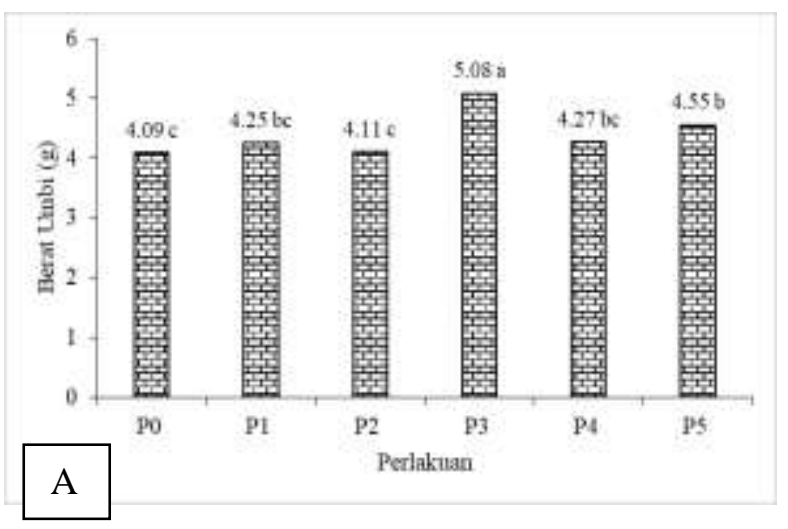




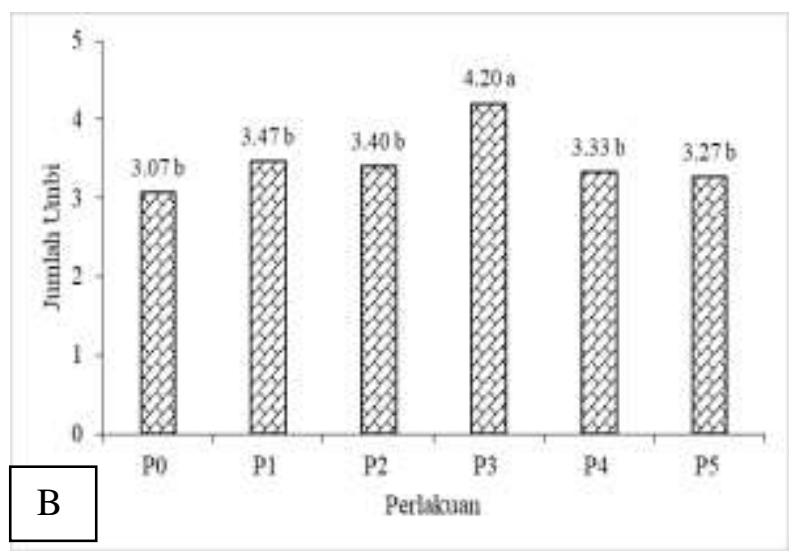

Gambar 5. Rata - rata jumlah umbi tanaman bawang merah yang diberikan perlakuan LEISA (5.A), Rata - rata berat umbi tanaman bawang merah yang diberikan perlakuan LEISA (5.B). Keterangan : Angka-angka yang diikuti oleh huruf yang tidak sama berbeda nyata pada UJBD taraf kepercayaan $95 \%$.

Hasil UJBD taraf kepercayaan 95\% pada Gambar 5.A menunjukkan bahwa teknik LEISA dengan perlakuan tertinggi terhadap berat umbi diperoleh pada perlakuan P3 yang berbeda tidak nyata dengan perlakuan $\mathrm{P} 5$, tetapi berbeda nyata dengan perlakuan P0,P1,P2 dan P4. Selain itu, pada Gambar 5.B menunjukkan bahwa teknik LEISA dengan perlakuan P3 memperoleh nilai tertinggi yang berbeda nyata dengan perlakuan LEISA lainnya. Hal penelitian menunjukkan kombinasi LEISA pada perlakuan P3 memberikan pengaruh yang baik terhadap pertumbuhan dan hasil tanaman bawang merah, dimana hal ini disebabkan adanya unsur hara penting dalam proses pembentukan umbi dan jumlah umbi yang terbentuk tidak terlepas dari peran unsur hara makro terutama unsur $\mathrm{P}$ dan $\mathrm{K}$. Unsur $P$ yang cukup untuk meningkatkan perkembangan akar dan kandungan karbohidrat, sedangkan unsur $\mathrm{K}$ berfungsi dalam pengisian dan pembentukkan umbi pada bawang merah. Hal ini sejalan dengan Munawar (2011) yang mengemukakan bahwa penambahan unsur $\mathrm{K}$ meningkatkan bobot umbi tanaman bawang merah karena kalium dapat meningkatkan proses metabolism tanaman dan pemanjangan sel. Selain itu, unsur kalium berperan dalam pengangkutan hasil fotosintesis.

\section{Produksi tanaman}

Hasil penelitian menunjukkan bahwa perlakuan LEISA memberikan pengaruh yang signifikan terhadap pertumbuhan dan hasil tanaman bawang merah. Hasil UJBD taraf kepercayaan $95 \%$ pada pengaruh perlakuan
LEISA terhadap produksi tanaman disajikan pada Gambar 6.

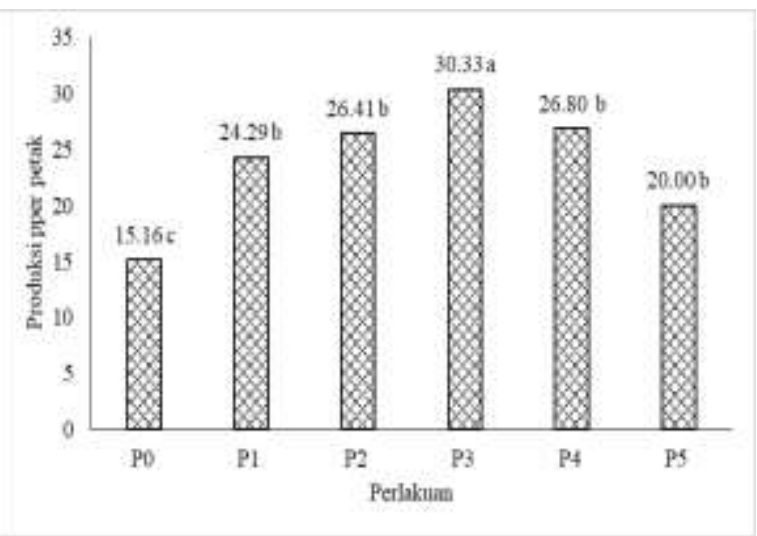

Gambar 6. Rata - rata produksi per petak tanaman bawang merah yang diberikan perlakuan LEISA. Keterangan : Angka-angka yang diikuti oleh huruf yang tidak sama berbeda nyata pada UJBD taraf kepercayaan $95 \%$.

Hasil UJBD taraf kepercayaan 95\% pada Gambar 6. menunjukkan bahwa teknik LEISA dengan perlakuan tertinggi terhadap produksi per petak diperoleh pada perlakuan P3 yang berbeda nyata dengan perlakuan LEISA lainnya. Peningkatan pertumbuhan tanaman bawang diduga juga dipengaruhi oleh penggunaan sistem LEISA. Firman et al. (2019) mengungkapkan bahwa pola LEISA berperan penting dalam meminimalkan penggunaan pupuk kimia yang berlebihan dengan menggabungkan pupuk organik dan anorganik untuk memaksimalkan pertumbuhan tanaman. Hasil penelitian menunjukkan bahwa perlakuan pupuk oganik 5 t.ha ${ }^{-1}+$ pupuk majemuk NPK dosis $250 \mathrm{~kg} \mathrm{ha}^{-1}$ pertumbuhan tanaman yang lebih tinggi dibandingkan dengan perlakuan. Hal ini diduga pupuk organik dan anorganik yang diaplikasikan ke tanah dapat mensuplai kebutuhan tanaman. Menurut bahwa pupuk organik termasuk pupuk kandang sapi dapat meningkatkan unsur N, P dan $\mathrm{K}$ yang merupakan unsur makro esensial yang dibutuhkan untuk pertumbuhan tanaman. Pupuk kadang sapi mengandung unsur hara Nitrogen, Fosfor dan Kalium secara berturut-turut sebesar $2, \quad 1,5$ dan $2,2 \%$. Selanjutnya penggunaan penggunaan pupuk majemuk NPK dapat menyediakan hara makro (NPK) yang dibutuhkan tanaman dalam jumlah banyak. Hara $\mathrm{N}$ dalam tanaman berfungsi sebagai pembentuk zat hijau daun (klorofil) dan unsur pembentuk protein. Hara $\mathrm{P}$ yang berfungsi sebagai penyimpan dan transfer energi, merupakan komponen penting dalam asam nukleat, koenzim, 
nukleotida, fospoprotein, fospolipid dan gula fosfat. Hara K berfungsi dalam pembentukan pati, mengaktifkan enzim dan katalisator penyimpanan hasil fotosintesis (Hartatik dan Widowati, 2010). Suntoro dan Astuti (2014), melaporkan bahwa perlakuan pupuk NPK dengan dosis $200 \mathrm{~kg} \mathrm{ha}^{-1}$ dengan meningkatkan produksi jagung sebesar 6, 77 t. ha ${ }^{-1}$ dibandingkan tanpa pemberian NPK. Lanjut Saberan et al. (2014), bahwa penggunaan pupuk NPK dengan dosis 375 t.ha- ${ }^{1}$ dapat meningkatkan pertumbuhan dan produksi tanaman tomat.

\section{Kesimpulan}

Berdasarkan hasil penelitian dapat disimpulkan bahwa teknik LEISA dengan perlakuan kombinasi Pupuk Organik 5 ton ha ${ }^{-1}+$ Pupuk NPK Majemuk $250 \mathrm{~kg} \mathrm{ha}^{-1}$ (P3) mampu meningkatkan pertumbuhan dan hasil tanaman bawang merah dibandingkan dengan perlakuan tanpa LEISA (P0). Pupuk Organik 5 ton $\mathrm{ha}^{-1}+$ Pupuk NPK Majemuk $250 \mathrm{~kg} \mathrm{ha}^{-1}$ (P3) berpengaruh nyata dalam meningkatkan tinggi tanaman, jumlah daun, jumlah anakan, berat kering, jumlah umbi, berat umbi dan produksi per per petak.

\section{Daftar Pustaka}

Aryanta, I.W.R. (2019). Bawang Merah dan Manfaatnya Bagi Kesehatan. E-Jurnal Widya Kesehatan, 1 (1).

BPS Kota Baubau. (2020). Kota Baubau dalam Angka 2020. Badan Pusat Statistik. Sulawesi Tenggara.

BPS Kota Baubau. (2021). Kota Baubau dalam Angka 2021. Badan Pusat Statistik. Sulawesi Tenggara.

Damanik, M.M.B., Hasibuan, B.E., Fauzi., Sarifuddin, H. \& Hanum. (2011). Kesuburan Tanah dan Pemupukan (p.40). Medan: USU Press.

Firman, A., Herlina, L. \& Yulianto, S. (2019). Analisis Low External Input Sustainable Agriculture (LEISA) pada Ternak Domba di Kawasan Agribisnis Desa Ternak, Desa Cintalaksana Kecamatan Tegalwaru, Kabupaten Karawang Analysis Of Low External Input Sustainable Agriculture (LEISA) In Agribisnis Livestock Zone At Cintalaksana Village, Tegalwaru Subdistrict, Karawang. Agribisnis Jurnal Pemikiran Masyarakat Ilmiah
Berwawasan Agribisnis, 5(1), 124-133.

Hartatik, W. \& Widowati, L.R. (2015). Pengaruh Pupuk Majemuk NPKS dan NPK Terhadap Pertumbuhan dan Hasil Padi Sawah pada Inceptisol. Penelitian Pertanian Tanaman Pangan, 34 (3).

Hidayat, T., Wardati, W. \& Armaini. (2013). Pertumbuhan dan Produksi Sawi (Brassica juncea L.) pada Inceptisol dengan Aplikasi Kompos Tandan Kosong Kelapa Sawit. $J$. Online Mahasiswa Fakultas Pertanian Universitas Riau, 1 (1), 1 - 9.

Isniah, U.S., \& Widodo. (2015). Eksplorasi Fusarium Non Patogen untuk Pengendalian Penyakit Busuk Pangkal Pada Bawang Merah. J Fitopatol Indones. 11(1), 14-22.

Munawar, A. (2011). Kesuburan Tanaman dan Nutrisi Tanaman (p.222). Bogor: Institut Pertanian Bogor Press.

Pangaribuan, D.H., Hendarto, K. \& Prihartini, K. (2017). Pengaruh Pemberian Kombinasi Pupuk Anorganik Tunggal dan Pupuk Hayati Terhadap Pertumbuhan dan Produksi Tanaman Jagung Manis (Zea mays saccharata Sturt) serta Populasi Mikroba Tanah. J. Floratek, 12 (1), 1-9.

Pradita, T. P., Yamika, W. S. D. \& Sumarni, T. (2018). Pengaruh Jarak Tanam Cabai Rawit (Capsicum frutescens L.) dan Populasi Oyong (Luffa acutangula) dalam Tumpangsari Terhadap Hasil Tanaman Cabai Rawit. J. Produksi Tanaman, 6 (1), $1-8$.

Rinasari, S. P. O., Z. Kadir, \& Oktafiri. (2016). Pengaruh Konsentrasi Pupuk Organonitrofos Terhadap Pertumbuhan dan Produksi Tanaman Tomat (Lycopersicon esculentum Mill.) Secara Organik dengan Sistem Irigasi Bawah Permukaan (sub surface irrigation). J. Teknik Pertanian Lampung, 4 (4), 325 234.

Setiyo, Y., Ida, B.P., Gunadnya., Ida B.W., Gunam \& I Ketut, B. (2017). The implementation of Low External Input Sustainable Agriculture System to Increase Productivity of Potato (Solanum tuberosum L.). Journal of Food, Agriculture \& Environment, 15 (2), 62-67. 
Suntoro \& Astuti, P. (2014). Pengaruh Waktu Pemberian dan Dosis Pupuk NPK Pelangi Terhadap Pertumbuhan Tanaman Jagung Manis Varietas Sweet Boys (Zea Mays Saccharata Sturt). Jurnal AGRIFOR, 13 (2), $1412-6885$.

Sutariati, G.A.K., Leomo, S. \& Rakian, T.C. (2014). Keragaan Pertumbuhan dan Hasil
Bawang Merah (Allium ascalonicum L.) pada Berbagai Ukuran Umbi dan Teknologi LEISA. AGRIPLUS, 24 (01), 0854-0128.

Tandi, O.G., Paulus, J., \& Arthur, P. (2015). Pertumbuhan dan Produksi Bawang Merah (Allium Ascalonicum L.) Berbasis Aplikasi Biourine Sapi. Eugenia, 21(3), 140-150. 